\title{
Seasonal Incidence of Campoletis chloridae Uchida-A Larval Parasitoid of Helicoverpa armigera (Hubner) on Chickpea
}

\author{
Rishi Pal ${ }^{1}$, Rajendra Singh*², Y.P. Malik ${ }^{3}$ and Awaneesh Kumar ${ }^{4}$ \\ ${ }^{1}$ Biocontrol Laboratory, ${ }^{2 \& 4}$ Deptt. of Entomology, Sardar Vallabhbhai Patel University of \\ Agriculture and Technology, Meerut - 250110( UP), India \\ ${ }^{3}$ Linseed Unit, Deptt. of Entomology, Chandra Shekhar Azad University of Agriculture and \\ Technology, Kanpur (U.P.) India \\ *Email: singhrajendra0113@gmail.com
}

\begin{abstract}
Study on seasonal incidence of Campoletis chloridae Uchida, a larval parasitoid of Helicoverpa armigera (Hubner), in chickpea crop was conducted at Kanpur during Rabi 2007-08. The parasitoid made its first appearing during $3^{\text {rd }}$ standard meteorological week of the year in different date of sowing and Varieties varied between 4.4 to $93.3 \%$. The Variety Udai sown at November 11-2007 D1 and D2 November 28 was Mean \pm SD $44.75 \pm 31.93$ and $42.61 \pm$ 27.65, Variety Avarodhi date of sown of October 212007 D1 and November 172007 D2 was Mean \pm SD 32.43 \pm 29.22 and $36.36 \pm 29.22$ and Variety Pragati date of sowing November 172007 D1 was Mean \pm SD $31.47 \pm 31.47$ \pm 26.79 during December, January, February and March respectively. The per cent parasitization of $C$. chloridae showed a negative correlation with means temperature, sunshine hours and relative humidity, while a significant positive correlation was found between per cent parasitization rainfall and wind velocity.
\end{abstract}

Kew Words: Chickpea, Campoletis chloridae Uchida, Helicoverpa armigera Hubner, Parasitization, incidence, weather parameters.

Paper cited: Pal, R., Singh, R., Malik, Y.P. and Kumar, A. (2016). Seasonal Incidence of Campoletis chloridae Uchida-A Larval Parasitoid of Helicoverpa armigera (Hubner) on Chickpea. South Asian Journal of Food Technology and Environment, 2(2): 393-398.

\section{Introduction}

\section{Chickpea (Cicer arietinum L)} commonly known as gram, Bengal gram, and garbanzo bean is only of the most important Rabi crop grown in India. The grains consist about 52-70 percent carbohydrate, 8-22 percent protein and 4-10 percent fat. The daily per capita availability is $14 \mathrm{gm}$ chickpea and a source of approximately $956 \mathrm{kcal}$ energy, 4-7 percent $(2.5 \mathrm{~g})$ protein to Indian population, besides being a major source of calcium and iron (Ali et al., 2003). Chickpea is raised over an area of 11.5 million ha in the world with a production of $8.58 \mathrm{MT}$ and productivity around $769.4 \mathrm{~kg} / \mathrm{ha}$ (FAO, 2004). India occupies first position in the world in term of area (64\%) during 2003-04. The crop occupies 5.12 million ha area with production of $5.79 \mathrm{MT}$ and $813 \mathrm{~kg} / \mathrm{ha}$ productivity (Kumar et al., 2005). Chickpea faces the attack of more than 60 insects-pests right from germination to maturity (Srivastava, 2005). Among them, gram pod borer, Helicoverpa armigera Hubner is considers as key pest causing 29\% yield losses in chickpea at national level. For effective management of Helicoverpa armigera Hubner greater emphasis is now being laid on Biological control, natural enemies play an important role in biological control. Among the different parasites and predators recorded, egg parasitoid, 
Trichogramma chilonis Ichchu is one of the potential of Helicoverpa armigera. However, parasitization by this species is rather negligible in chickpea ecosystem (Yadav and Patel, 1981). Campoletis chloridae Uchida has been reported widely distributed and potential parasite of Helicoverpa armigera Hubner damaging chickpea crop (Ahmed and Khan, 1995; Nikam and Gaikwad, 1990; Patnaik et al, 1991; Yadav et al., 1991). However detail information on its degree of parasitization during different months of crop period studies were under taken on the seasonal occurrence and extent of parasitization in relation to crop phenology.

\section{Materials and methods}

The investigation on the natural parasitization of gram pod borer on chickpea Varieties (Avarodhi, Udai (KPG-59) and Pragati) sown on different dates, were conducted under laboratory condition. For this purpose, twenty larvae of first/second instar were collected each field, at student Instruction Farm, Crop research Farm, Nawabganj, Old dairy Farm and oil Farm and Oiled seed Research farm, Kalayanpur and laboratory of Department of Entomology C.S.A. University of Agriculture and Technology Kanpur (U.P.) during rabi. First second instar was selected because only these stages are parasitized by Campoletis chloridae Uchida (Nikam and Gaikwad et al., 1991). The collection of larvae was carried out during morning hours and brought to the laboratory for further rearing. To avoid cannibalism each larvae were kept in separate glass vial. The glass vials were labeled with date of collection etc. In this manner each day larval collection was kept in separate plastic tray to avoid mixing. Every day the glass vials were cleaned for excreta, and fresh chickpea leaves were provide. Observations were recorded regularly on extent of parasitization. It was observed that larvae which were parasitized by Campoletis chloridae Uchida change into a typical cocoon of parasite during the first/ second larval instar it. However, unparasitized larvae of Helicoverpa armigera Hubner grew to the further instars and shaped into normal pupa from which adult moth emerged out. These were some natural mortality of the larvae. The data on maximum and minimum temperature, relative humidity, sunshine hours, and rainfall and wind velocity prevailing during the crop season was collected from Department of Agronomy of University, which were converted as according to the standard weeks. The data were correlated with the population of pod borer.

$$
\begin{array}{r}
\text { Parasitization }(\%)= \\
\text { Number of parasitized larvae } \\
\text { Total number of larvae recorded }
\end{array}
$$

\section{Results and discussion}

To find out the natural parasitization of Campoletis chloridae Uchida, collection and rearing of first, second instar larvae of Helicoverpa armigera Hubner started in the month of December in the chickpea field from each date of sowing of Varieties up to March during the year 2008. Data collected during the course of study were summarized in Table 1. The parasitization of the larvae occurred at the slower rate being 6.66 to 15.10 percent in $50^{\text {th }}$ standard week (Mid December) showing the highest parasitization of the larvae collected from chickpea Variety sown in last week of November larval parasitization on chickpea Variety Udai varies between 5 to 93.33 and 0 to 85.30 percent $3^{\text {rd }}$ and $4^{\text {th }}$ week of November sown crop respectively. The parasitization was recorded 13.33 to 28.89 percent in first week of January on different date of sowing chickpea. Second week of January ( $2^{\text {nd }}$ standard week) to end February ( $9^{\text {th }}$ standard week) was observed the parasitization varied between 45.0 to 93.33 , 50.00.to $85.30,25.00$ to $80.00,35.00$ to 85.70 and 30.00 to 80.00 percent on chickpea Variety Udai sown in $3^{\text {rd }}$ and $4^{\text {th }}$ week of November, 
respectively. Average parasitization was highest 44.75 percent on $3^{\text {rd }}$ week of November sown chickpea fallowed by 42.61, 39.36, 32.43 and 31.47 percent parasitization recorded in Udai sown $4^{\text {th }}$ week of November, Avarodhi sown $3^{\text {rd }}$ week of October and Pragati sown in $3^{\text {rd }}$ week of November respectively. Based on a have cited result, it can be summarized that parasitization of the larvae of gram pod borer by its natural parasite, Campoletis chloridae Uchida suppressed well below economic thresh hold level during vegetative phase of the crop on all the Variety of chickpea sown at different date. But the parasitization was noticed in decreasing manner during reproductive phase of crop resulting in higher intensity of gram pod borer particularly in late sown crop. Higher extent of parasitization ranging between 25.00 to 93.33 percent by the Ichenumoid wasp, Campoletis chloridae Uchida during January, February was observed in present finding, which was in conformity with those Srinivasan (1989), Sachan and Bhaumik (1998), Kaur et al., (2000) and Rai et al., (2003). They reported the higher parasitization by Campoletis chloridae Uchida to be $43.9,80.64,68.50$ and 41.00 percent during, December, January, February and March, respectively.

\section{Effect of Weather on parasitization}

The larvae of gram pod borer in chick pea under natural condition were found to be parasitizes by $C$. chloridae immediately after ignition of its incidence during mid December irrespective of Varietiesand sowing dates (Table 1). Significant negative correlation $(\mathrm{r}=-0.4818$ to -0.5139) was established between the larval intensity and its parasitization (Table 2). As the pest intensity increased towards the end of
December crossing the economic threshold level on almost all Varietiesand sowing dates, its parasitization was also found increase. Yadav and Lal (1988) reported the correlation coefficient were found to be positive significant in case of maximum and minimum temperature but negative non-significant with relative humidity and per cent parasitization. Higher parasitization ranging between 26.666 to 93.33 percent was noticed during January-February on chickpea Varieties sown different dates with its mean 24.35 to 78.98 percent in different weeks this period.

Gupta and Raj (2003) observed multiple regression analysis significant effect of relative humidity and total rainfall on parasitization both individually as well as biotic factors was upto the extent of 74.15 per cent. The parasitization of the pest was influenced negatively by the temperature (maximum, minimum and average) and minimum relative humidity. Rainfall and wind velocity showed their insignificant positive impact on the parasitization, while sun shine hours were correlated negatively. The evaporation rate could show significant negative relationship on the parasitization of the pest population collected from second fortnight of the November sown crop. Since the observation on parasitriuzation of field collected larvae of gram pod borer by the parasitoid, C. chloridae were under taken in laboratory at the room temperature, the effect of weather parameter on the parasitization was not distinct. However, negative impact of temperature and minimum relative humidity, evaporation rate and sunshine hours was noticed on parasitization of this pest, while maximum relative humidity, rainfall and wind velocity had shown their positive impact. 
Table 1: Weekly Parasitization (\%) of gram pod borer on chickpea Varieties sown at different dates by parasitoid Compoletis chloridae

\begin{tabular}{|c|c|c|c|c|c|c|c|c|c|c|c|c|c|c|c|c|c|c|}
\hline \multirow[t]{3}{*}{ Variety } & \multirow{3}{*}{$\begin{array}{l}\text { Date of } \\
\text { sowing }\end{array}$} & \multicolumn{17}{|c|}{ Parasitization \% } \\
\hline & & \multicolumn{4}{|c|}{ December } & \multicolumn{5}{|c|}{ January } & \multicolumn{4}{|c|}{ February } & \multicolumn{3}{|c|}{ March } & \multirow{2}{*}{$\begin{array}{c}\text { Mean } \pm \\
\text { SD }\end{array}$} \\
\hline & & 49 & 50 & 51 & 52 & 1 & 2 & 3 & 4 & 5 & 6 & 7 & 8 & 9 & 10 & 11 & 12 & \\
\hline \multirow[t]{2}{*}{$\begin{array}{l}\text { Udai } \\
\text { (KGB-59) }\end{array}$} & $\begin{array}{l}\text { Nov.11,200 } \\
7 \\
\text { (D1) }\end{array}$ & 0 & 8.33 & 11.3 & 15.55 & 28.89 & 71.11 & 75.55 & 85.71 & 86.66 & 93.33 & 70.00 & 64.70 & 45.00 & $\begin{array}{c}35.0 \\
0\end{array}$ & $\begin{array}{c}20.0 \\
0\end{array}$ & $\begin{array}{c}5.0 \\
0\end{array}$ & $\begin{array}{c}44.75 \pm 31.9 \\
3\end{array}$ \\
\hline & $\begin{array}{l}\text { Nov.28,200 } \\
7 \\
\text { (D2) }\end{array}$ & 0 & 15.10 & 17.78 & 20.0 & 26.67 & 71.11 & 80.70 & 85.30 & 70.00 & 60.00 & 65.00 & 65.00 & 50.00 & $\begin{array}{c}30.0 \\
0\end{array}$ & $\begin{array}{c}20.0 \\
0\end{array}$ & 0 & $42.6 \pm 27.65$ \\
\hline \multirow[t]{2}{*}{ Avrodhi } & $\begin{array}{l}\text { Oct. } 21,2007 \\
\text { (D1) }\end{array}$ & 0 & 0 & 4.44 & 6.67 & 13.33 & 60.00 & 62.00 & 68.89 & 80.00 & 73.33 & 65.00 & 25.00 & 30.00 & $\begin{array}{c}20.0 \\
0\end{array}$ & $\begin{array}{c}10.0 \\
0\end{array}$ & 0 & $\begin{array}{c}32.43 \pm 29.2 \\
2 \\
\end{array}$ \\
\hline & $\begin{array}{l}\text { Nov.17,200 } \\
7 \\
\text { (D2) }\end{array}$ & 0 & 6.66 & 20.00 & 22.22 & 28.89 & 80.00 & 85.70 & 80.00 & 60.00 & 60.00 & 71.40 & 40.00 & 35.00 & $\begin{array}{c}20.0 \\
0\end{array}$ & $\begin{array}{c}20.0 \\
0\end{array}$ & 0 & $\begin{array}{c}39.36 \pm 28.5 \\
5\end{array}$ \\
\hline Pragati & $\begin{array}{l}\text { Nov.17,200 } \\
7 \\
\text { (D1) }\end{array}$ & 0 & 0 & 17.78 & 24.7 & 24.44 & 40.00 & 80.00 & 75.00 & 70.00 & 60 & 45.00 & 26.00 & 30.00 & 5.00 & 5.00 & 0 & $\begin{array}{c}31.47 \pm 26.7 \\
9\end{array}$ \\
\hline Mean \pm SD & & 0 & $\begin{array}{c}6.13 \\
\pm \\
7.02\end{array}$ & $\begin{array}{c}10.13 \\
\pm \\
7.02\end{array}$ & $\begin{array}{c}17.82 \\
\pm \\
6.33\end{array}$ & $\begin{array}{c}24.35 \\
\pm \\
5.79\end{array}$ & $\begin{array}{c}64.44 \\
\pm \\
13.77\end{array}$ & $\begin{array}{c}76.83 \\
\pm \\
7.90\end{array}$ & $\begin{array}{c}78.98 \\
\pm \\
6.38\end{array}$ & $\begin{array}{c}73.73 \\
\pm \\
9.18\end{array}$ & $\begin{array}{c}69.33 \\
\pm \\
13.06\end{array}$ & $\begin{array}{c}63.20 \\
\pm \\
9.43\end{array}$ & $\begin{array}{c}44.27 \\
\pm \\
11.50\end{array}$ & $\begin{array}{c}38.00 \pm 8.1 \\
2\end{array}$ & $\begin{array}{c}22 \pm \\
10.2 \\
9\end{array}$ & $\begin{array}{l}15 . \pm \\
6.32\end{array}$ & $\begin{array}{c}2 \pm \\
2.4 \\
5\end{array}$ & $38.12 \pm 5.33$ \\
\hline
\end{tabular}

Table 2: Simple Correlation Coefficient (r) parasitization (\%) of larvae of gram pod borer on chickpea Varieties sown at different dates and whether factors.

\begin{tabular}{|c|c|c|c|c|c|c|c|c|c|c|c|}
\hline \multirow[t]{2}{*}{ Variety } & \multirow{2}{*}{$\begin{array}{c}\text { Sowing } \\
\text { Date }\end{array}$} & \multicolumn{3}{|c|}{ Temperature (0c) } & \multicolumn{3}{|c|}{ Relative Humidity (\%) } & \multirow{2}{*}{$\begin{array}{c}\text { Rainfall } \\
\text { (cm) }\end{array}$} & \multirow{2}{*}{$\begin{array}{c}\text { Wind } \\
\text { velocity } \\
(\mathrm{km} / \mathrm{hr})\end{array}$} & \multirow{2}{*}{$\begin{array}{c}\text { Evaporation } \\
\text { rate } \\
\text { (mm/day) }\end{array}$} & \multirow{2}{*}{$\begin{array}{c}\text { Sunshine } \\
\text { hours } \\
\text { (hrs/day }\end{array}$} \\
\hline & & Max & Min. & Max & Min. & Max & Min. & & & & \\
\hline \multirow[t]{2}{*}{$\begin{array}{l}\text { Udai } \\
\text { (KPG-59 }\end{array}$} & $\begin{array}{l}\text { Non.11, } \\
\text { 2007(D1) }\end{array}$ & -0.4657 & -0.3566 & -0.3955 & -0.0256 & -0.1223 & -0.0397 & 0.0312 & 0.2978 & -04717 & -0.2622 \\
\hline & $\begin{array}{l}\text { Non.28, } \\
\text { 2007(D2) }\end{array}$ & -0.4714 & -0.3544 & -0.3592 & -0.0633 & -0.1460 & -0.0520 & 0.2263 & 0.2403 & $-0.5086^{*}$ & -0.2687 \\
\hline \multirow[b]{2}{*}{ Avrodhi } & $\begin{array}{l}\text { Oct.21, } \\
2007(\mathrm{D} 1)\end{array}$ & -0.4736 & -0.3659 & -0.4322 & -0.2938 & -0.2553 & -0.2586 & 0.1601 & 0.0761 & -0.4563 & -0.1808 \\
\hline & $\begin{array}{l}\text { Nov.17 } \\
2007(D 1)\end{array}$ & -0.3979 & -0.2982 & -0.3582 & -0.3173 & -0.3382 & -0.3636 & 0.0031 & 0.3776 & $-0.5506^{*}$ & -0.1436 \\
\hline Pargati & $\begin{array}{l}\text { Nov.17 } \\
2007(\mathrm{D} 1)\end{array}$ & -0.3444 & -0.4794 & -0.6124 & -0.1180 & -0.1892 & -0.0676 & 0.0603 & 0.0725 & -0.5229 & -0.3386 \\
\hline Mean & & 0.4306 & -0.3709 & 0.4316 & -0.1636 & -0.2102 & -0.1563 & 0.0962 & 0.2128 & -0.5033 & -0.2387 \\
\hline
\end{tabular}

NB: *Significant at $5 \%$, level of significance, respectively. 


\section{Conclusion}

The larvae of gram pod borer in chick pea under natural condition were found to be parasitizes by $C$. chloridae immediately after ignition of its incidence during mid December irrespective of Varieties and sowing dates. Since the observation on parasitization of field collected larvae of gram pod borer by the parasitoid, C. chloridae were under taken in laboratory at the room temperature. The effect of weather parameter on the parasitization was not distinct. However, negative impact of temperature and minimum relative humidity, evaporation rate and sunshine hours was noticed on parasitization of this pest, while maximum relative humidity, rainfall and wind velocity had shown their positive impact.

\section{Reference}

1. Ahmed, K.N. and Khan, A.R. (1995). Biological note on Campoletis chloridae Uchida (Hymenoptera: Ichneumonidae). Bangladesh Journal of Zoology, 23 (2): 243-244.

2. Ali, M. and Kumar, S. (2003). Chickpea research in India an overview. In: Chickpea Research in India (Eds. M. Ali, Shiv Kumar and N.B. Singh), Indian Instate of pulses Research, Kanpur (India), pp. 229-260.

3. Gupta, P.K. and Raj, D. (2003). Natural parasitization by Campoletis chloridae a promising parasitoid of Helicoverpa armigera Hubner on chickpea. Journal of Biological Control, 17(1): 9-12.

4. Kaur, S., Brar, K.S., Sakhon, B.S., Joshi, N., Shenmar, M. and Singh, J. (2000). Role played by Campoletis chloridae in natural mortality of Helicoverpa armigera Hubner on chickpea in Punjab. Journal of Biological Control, 14 (1): 51-54.

5. Kumar. H., Devraj and Kumar, S. (2005). Production Scenario of chickpea in India: Growth and decomposition analysis.
Indian Journal of Pulses Research, 18(2):199-201.

6. Nikam, P.K. and Gaikwad, A.M. (1991). Effect of host larvae of Helicograph armigera Hubner on the parasitizing ability of Campoletis chloridae Uchida. Entomo, 16: 301-303.

7. Nikam, P.K. and Gaikwad, A.M. (1998). Role of Hymenopterans parasitoids in the biological control of Heliothis armigera Hubner (Lepidoptera: Noctuidae) with special reference to Campoletis chloridae Uchida (Hymenopterans: Ichneumonidae) in India. Journal of Entomology Research, 13: (1-2) 6-20.

8. Patnik, H.P., Rath, L.K., Senapati, B. and Behera, P.K. (1991). Incidence of Helicoverpa armigera Hubner on chickpea and its production phenology in North Central plateau Zone of Orissa. Orissa Journal of Agricultural Research, 4(3-4): 137-142.

9. Rai, D., Vjagir, R. and Singh, R.K. (2003). The larval parasitization by Campoletis chloridae Uchida of Helicoverpa armigera Hubner in pure chickpea crop at Pantnagar. Journal of Biological Control, 17 (1): 81-83.

10. Sachan, J.N. and Bhaumik, K.R. (1998). Extent of parasitization of Campoletis chloridae Uchida a larval parasite of Helicoverpa armigera Hubner chickpea. Indian Journal of Pulses Research, 11(2): 65-69.

11. Srinivsan, R.P. (1989). Extent of parasitization of gram pod bore, Helicoverpa armigera Hubner by Ichneumon larval parasites. Indian Journal of Agricultural Science, 59 (6): 377-378.

12. Srivastava, C.P., Ahmad, R., Ujagir, R and Das, S.B. (2005). Helicoverpa armigera Hubner Management in pulses Present Scenario and future strategies, In: Recent 
advances in Helicoverpa armigera Management, ( Eds. H. Sexena, A.B. Rai, R. Ahamad and Sanjeev Gupta), Indian Society of Pulses Research and Development, Indian Institute of Pulses Research, Kanpur (India). pp. 265-286.

13. Yadav, C.P. and Lal, S.S. (1988). Relationship between certain a biotic and biotic factors and occurrence of gram pod borer, Helicoverpa armigera Hubner on chickpea. Entomon, 13 (3\& 4): 269-273.

14. Yadav, C.P., Sachan, J.N., Ahamad, R. and Lal, S.S. (1991). Natural enemies of insects infesting chickpea and pigeonpea in Kanpur. Journal of Biological Control, 5 (1): 52-54.

15. Yadav, D.N. and Patel, R.C. (1981). Egg parasitism of Helicoverpa armigera Hubner (Lepidoptera: Noctuidae) in Gujarat. Gujarat Agricultural University Research Journal, 7: 19-22. 